\title{
Yerba Mate (Ilex Paraguariensis A. St. Hil) and Risk Factors for Cardiovascular Diseases
}

\author{
Patricia de Moraes Pontilho MPH ${ }^{1}$, Andrea Mariana Nunes da Costa Teixeira MPH ${ }^{1}$, Caterina Yuan BSc $^{2}$, \\ Liania Alves Luzia ${ }^{1, *}$, Deborah Helena Markowicz Bastos ${ }^{1}$, Patricia Helen Rondó ${ }^{1}$ \\ ${ }^{1}$ Nutrition Department, School of Public Health, University of Sao Paulo-USP. Av Dr Arnaldo, 715, São Paulo, SP, 01246-904, Brazil \\ ${ }^{2}$ Harvard College, Boston-MA, United States of America. 326 Cambridge St \#410, Boston, MA 02114, USA \\ *Corresponding author: lianialuzia@usp.br
}

Received February 06, 2015; Revised February 26, 2015; Accepted March 22, 2015

\begin{abstract}
Cardiovascular diseases (CVDs) are the main cause of death worldwide. Risk factors for CVDs include increased blood pressure, dyslipidemia, overweigh/obesity and type 2 diabetes mellitus (T2DM). Yerba Mate (YM) is an herbal preparation obtained from twigs and leaves of Ilex paraguariensis that seems to provide cardiovascular benefits, improving the lipid profile and preventing cholesterol oxidation. Considering that most of the drugs that have an impact on lipid profile, show several adverse effects, we aimed to review the benefits of YM in the prevention of CVDs, since the use of plant extracts has little or no side effects. The search included articles published up to September 2014, using the "PubMed" and "Food Science and Technology Abstracts-FSTA" databases with the descriptor Ilex paraguariensis. Two hundred and twenty six (226) and 132 articles were identified at PubMed and FSTA, respectively, but 71 were common for both databases. Given that only 1 article was obtained when the descriptors I. paraguariensis and cardio* were utilized in the search, the authors decided to read the 287 abstracts found in PubMed and FSTA databases. From those, 22 articles were eligible because they assessed the associations between I. paraguariensis, yerba mate (or its main compounds) and the following risk factors for CVDs: oxidative stress, atherosclerosis, dyslipidemia, overweight/obesity and T2DM. YM consumption apparently has antioxidant, vasodilation, cholesterol lowering, anti-obesity and anti-diabetic effects. However, the mechanism by which YM exerts these effects is still not clear. Thus, we advise future clinical trials using YM in humans at risk for CVDs.
\end{abstract}

Keywords: Yerba mate, Ilex paraguariensis, cardiovascular diseases, antioxidants, obesity, diabetes

Cite This Article: Patricia de Moraes Pontilho MPH, Andrea Mariana Nunes da Costa Teixeira MPH, Caterina Yuan BSc, Liania Alves Luzia, Deborah Helena Markowicz Bastos, and Patricia Helen Rondó, "Yerba Mate (Ilex Paraguariensis A. St. Hil) and Risk Factors for Cardiovascular Diseases." Journal of Food and Nutrition Research, vol. 3, no. 3 (2015): 182-190. doi: 10.12691/jfnr-3-3-9.

\section{Introduction}

Cardiovascular diseases (CVDs) are the main cause of death globally, killing more than 17.1 million people each year (29\% of all deaths). Risk factors for CVDs include chronic and progressive disorders, such as dyslipidemia, overweight/obesity and type-2 diabetes mellitus (T2DM) [1]. Although effective and inexpensive medication is available to treat individuals with CVDs, some may have negative side effects [2]. Given the rising burden of chronic diseases, it is of interest to find effectual, natural products with few side effects that can prevent or improve illness.

Yerba Mate (YM) is an antioxidant-rich herbal preparation that has been suggested to provide cardiovascular benefits, including improvement of the lipid profile and prevention of cholesterol oxidation [3]. It is prepared from the leaves and branches of Ilex paraguariensis A. St. Hil and is commonly consumed instead of coffee in Southern Brazil, Argentina, Paraguay and Uruguay $[4,5]$.

YM leaves are used to prepare different beverages, such as chimarrao (green dried leaves brewed with hot water in a vessel called "cuia”), terere (green dried leaves brewed with cold water in a "cuia"), and mate tea (roasted leaves brewed with hot water or used to produce soft drinks) [6].

In this article YM refers to I. paraguariensis beverages and extracts. The preparation of I. paraguariensis leaves, as well as the variety and cultivation system of the plant affects the final chemical content of the beverage $[3,7,8]$. YM contains several bioactive compounds (Table 1), including polyphenols (chlorogenic acid), xanthines (caffeine, theobromine), and saponins (derived from ursolic and oleanolic acid), which may exert cardiovascular effects [3,9]. Among the active phytochemicals in YM extract, the two highest are polyphenols (phenolic acids) and xanthines (caffeine and theobromine). The main phenolic acids are 5caffeoylquinic acid (5-CQA), caffeic acid, 3,4dicaffeoylquinic acid, 3,5-dicaffeoylquinic acid, 4,5dicaffeoylquinic acid and flavonoids (quercetin, 
kaempferol, and rutin) $[3,10,11]$. The aim of the present review was to evaluate the possible benefits of YM in preventing risk factors for CVDs.

Table 1. Bioactive compounds of Yerba Mate with potential cardiovascular benefits

\begin{tabular}{cc}
\hline Compounds & Benefits \\
\hline Caffeine and theobromins & Central nervous system stimulant, \\
vasodilator \\
Chlorogenic acids, caffeic acid & Antioxidant activity \\
Saponins (from ursolic and & Cholesterol lowering, \\
oleanolic acid) & antiperoxidant \\
Quercetin and rutin & Antioxidant activity, vasodilator \\
\hline
\end{tabular}

\section{Methods}

The literature review was carried out in databases PubMed - "http://www.ncbi.nlm.nih.gov/pubmed U.S. National Library of Medicine, National Institutes of Health" with descriptor Ilex paraguariensis [MESH] OR Ilex paraguariensis in free term, and in FSTA - "Food Science and Technology Abstracts” with descriptor (Ilex paraguariensis OR yerba mate) all fields. Each Database was searched up to September, 2014. No ageing, gender, species or language restrictions were imposed.

Table 2. In vivo effect of Yerba Mate on potential risk factors for cardiovascular diseases in animals

\begin{tabular}{|c|c|c|c|c|c|}
\hline References & Sample, period and type of intervention & Preparation of YM & $\begin{array}{c}\text { Active } \\
\text { compounds }\end{array}$ & Main findings & Conclusions \\
\hline $\begin{array}{l}\text { Bravo et al } \\
(2014)^{32}\end{array}$ & $\begin{array}{c}n=24 \text { (Wistar rats); } 3 \text { wk; } 4 \text { groups: SW, SM, } \\
\text { HW, HM. }\end{array}$ & $\begin{array}{l}50 \mathrm{~g} \text { of YM in } 1 \mathrm{~L} \\
\text { of boiling water. } \\
\text { Free access to } \\
\text { drinking fluids } \\
\end{array}$ & $\begin{array}{l}8 \mathrm{~g} / 100 \mathrm{~g} \text { of } \\
\text { phenolic, } 5.5 \mathrm{mg} / \mathrm{g} \\
\text { of Saponin }\end{array}$ & $\begin{array}{c}\downarrow \text { TG, LDL-c, and serum } \\
\text { MDA levels, but no HDL-c } \\
\text { in hypercholesterolemic } \\
\text { rats. } \\
\end{array}$ & $\begin{array}{l}\text { Restricted to } \\
\text { hyperlipidemic } \\
\text { animals. }\end{array}$ \\
\hline $\begin{array}{l}\text { Gao et al } \\
(2013)^{33}\end{array}$ & $\begin{array}{l}\mathrm{n}=50 \text { (Syrian golden hamsters) } 4 \mathrm{wk} \text {; } 5 \\
\text { groups: NC, HFD, low-dose YM (HFD+ 1\% } \\
\text { YM), a middle-dose YM (HFD+ 2\% YM) and } \\
\text { a high-dose YM (HFD+ 4\% YM) }\end{array}$ & $\begin{array}{l}\text { 40, } 20 \text { and } 10 \\
\mathrm{mg} / \mathrm{mL}(\mathrm{w} / \mathrm{v}) \text {. Free } \\
\text { access to drinking } \\
\text { fluids }\end{array}$ & $\begin{array}{c}1.23 \mathrm{mg} / \mathrm{g}, \\
\text { Caffeine; } 0.18 \\
\text { mg/g, } \\
\text { theobromine; } 2.11 \\
\text { mg/g, CGA; } 0.03 \\
\text { mg/g, Caffeic acid } \\
\end{array}$ & $\begin{array}{l}\text { Anti-obesity and } \\
\text { hypolipidemic effects in } \\
\text { hyperlipidemic hamster } \\
\text { model. }\end{array}$ & $\begin{array}{c}\downarrow \text { lipid } \\
\text { peroxidation. } \\
\uparrow \text { endothelial } \\
\text { function and LPL } \\
\text { and HL activities }\end{array}$ \\
\hline $\begin{array}{l}\text { Gao et al } \\
(2013)^{28}\end{array}$ & $\begin{array}{c}\mathrm{n}=60 \text { (Sprague-Dawley rats) } 8 \mathrm{wk}, 5 \text { groups: } \\
\text { NC, low-dose YM (HFD+ 1\%YM), middle- } \\
\text { dose YM (HFD+2\%YM) and high-dose YM } \\
(\text { HFD+4\%YM) }\end{array}$ & $\begin{array}{l}\text { 40, } 20 \text { and } 10 \\
\mathrm{mg} / \mathrm{mL}(\mathrm{w} / \mathrm{v}) \text {. Free } \\
\text { access to drinking } \\
\text { fluids }\end{array}$ & $\begin{array}{l}340 \mathrm{mg} / \mathrm{mL} \text { of } \\
\text { phenolic }\end{array}$ & $\begin{array}{c}\downarrow \text { Endothelin and TXB2 } \\
\text { levels and } \uparrow \text { NO and 6- } \\
\text { keto-PGF1 } \alpha \text { levels in the } \\
\text { blood. } \downarrow \text { ICAM- } 1 \text { and up } \\
\text { regulated mRNA } \\
\text { expression of hepatic } \\
\text { LDLR and SR-B1. }\end{array}$ & $\begin{array}{l}\text { Regulatory effect } \\
\text { on blood fat and } \\
\text { endothelial } \\
\text { function. }\end{array}$ \\
\hline $\begin{array}{l}\text { Kang et al } \\
(2012)^{48}\end{array}$ & $\begin{array}{c}\mathrm{n}=10 \text { (C57BL/6J mice); } 4 \text { wk; } 5 \text { groups: NC, } \\
\text { HFD, HFD + (0.5,1.0 and } 2.0 \mathrm{~g} / \mathrm{kg})\end{array}$ & $\begin{array}{c}0.5,1 \text {, or } 2 \mathrm{~g} / \mathrm{kg} \\
\text { body weight by } \\
\text { intragastric Gavage }\end{array}$ & Unknown & $\begin{array}{l}\downarrow \mathrm{TC}, \mathrm{TG}, \text { and glucose } \\
\text { concentrations }\end{array}$ & $\begin{array}{c}\text { Anti-obesity and } \\
\text { hypoglycemic }\end{array}$ \\
\hline $\begin{array}{l}\text { Pereira et } \\
\text { al (2012) }\end{array}$ & $\begin{array}{c}\mathrm{n}=36 \text { (Wistar rats); } 180 \text { min } 6 \text { groups: } \mathrm{I}=\mathrm{NC} \text {, } \\
\mathrm{II}=\text { glucose }(4 \mathrm{~g} / \mathrm{kg}), \mathrm{III}=\text { glucose plus EtOAc, } \\
\mathrm{IV}=\text { glucose plus } \mathrm{n}-\mathrm{BuOH}, \mathrm{V}=\text { glucose plus } \\
\text { aqueous extract of green } \mathrm{YM} \text { infusion, } \mathrm{VI}= \\
\text { glucose plus aqueous extract of roasted } \mathrm{YM} \\
\text { infusion }\end{array}$ & $\begin{array}{l}\text { All treatments } \\
\text { were made orally } \\
\text { by gavages }\end{array}$ & $\begin{array}{c}\text { YM Roasted, } \\
277.10 \mathrm{mg} / \mathrm{g} \\
\text { YM Green } 271.08 \\
\text { mg/g) } \\
\text { Of phenolic }\end{array}$ & $\begin{array}{l}\text { The green YM infusion } \\
\text { was apparently more } \\
\text { efficient in reducing the } \\
\text { serum glucose levels. }\end{array}$ & $\begin{array}{l}\text { Anti- } \\
\text { hyperglycemic } \\
\text { effect }\end{array}$ \\
\hline $\begin{array}{l}\text { Resende } e t \\
\text { al (2012) }\end{array}$ & $\begin{array}{c}\mathrm{n}=24 \text { (Wistar rats); } 4 \text { wk } 4 \text { groups: A, LAE ad } \\
\text { libitum ( } 24.7 \mathrm{mg} \text { of dried residue/mL); B, } 500 \\
\mu \mathrm{g} / \mathrm{mL} \text { of FHE ad libitum; C, } 500 \mu \mathrm{g} / \mathrm{mL} \text { of } \\
\text { MSF ad libitum. D (control group) }\end{array}$ & $\begin{array}{l}70 \mathrm{~g} \text { of } \mathrm{YM} \text { in } 1 \mathrm{~L} \\
\text { of water }\left(80^{\circ} \mathrm{C} \text { for }\right. \\
15 \text {-min) }\end{array}$ & $\begin{array}{l}\text { LAE, FHE, MSF } \\
(4904.09,9.79 \\
\text { ND) }(\mu \mathrm{g} / \mathrm{mL}) \\
\text { total polyphenols }\end{array}$ & $\begin{array}{l}\downarrow \text { TG in MSF and LAE } \\
\text { groups. } \\
\uparrow \text { glucose blood level in } \\
\text { FHE group. }\end{array}$ & $\begin{array}{l}\downarrow \text { fat weight, } \\
\text { plasma TG, and } \\
\text { both liver and fat } \\
\text { tissues glucose } \\
\text { oxidation }\end{array}$ \\
\hline $\begin{array}{l}\text { Hussein et } \\
\text { al (2011) }\end{array}$ & $\begin{array}{c}\mathrm{n}=30 \text { (Tsumura Suzuki mice); } 7 \text { wk } 3 \text { groups: } \\
\text { NC-TSNO, and two TSOD groups }\end{array}$ & $\begin{array}{l}\text { Powdered dry fresh } \\
\text { leaves of YM by } \\
\text { infusion with } \\
\text { boiling water } \\
\left(95^{\circ} \mathrm{C}\right)\end{array}$ & $\begin{array}{l}41.3 \mathrm{mg} / \mathrm{mL} \text { of } \\
\text { total phenolic } \\
\text { content }\end{array}$ & $\begin{array}{l}\downarrow \text { TG, NEFAs, and TC, } \\
\text { improve adiponectin level, } \\
\text { and } \downarrow \text { white adipose tissue } \\
\text { weight, and adiposity } \\
\text { index. }\end{array}$ & $\begin{array}{l}\text { Effects on IR, } \\
\text { diabetes, and } \\
\text { dyslipidemia }\end{array}$ \\
\hline $\begin{array}{l}\text { Silva et al } \\
(2011)^{50}\end{array}$ & $\begin{array}{c}\mathrm{n}=15 \text { (Wistar rats); } 4 \text { wk; } 3 \text { groups: CW, CM } \\
\text { and GM }\end{array}$ & $\begin{array}{l}70 \mathrm{~g} \text { of } \mathrm{YM} \text { in } 1 \mathrm{~L} \\
\text { of water }\left(80^{\circ} \mathrm{C} \text { for }\right. \\
15 \text {-min) ad libitum } \\
\text { (as the only way to } \\
\text { hydration) }\end{array}$ & $\begin{array}{l}\text { Total polyphenols } \\
\text { contents (mg/mL) } \\
7.42(\mathrm{GM}) \text { and } \\
7.30(\mathrm{CM})\end{array}$ & $\begin{array}{l}\text { YM did not change body } \\
\text { weight gain and lipid } \\
\text { profile. } \\
\uparrow \text { blood glucose and } \downarrow \\
\text { epididymal and intra- } \\
\text { abdominal deposits } \\
\end{array}$ & $\begin{array}{c}\text { Anti-obesity } \\
\text { effect of GM but } \\
\text { increase in blood } \\
\text { glucose }\end{array}$ \\
\hline $\begin{array}{l}\text { Martins et } \\
\text { al (2010) }\end{array}$ & $\begin{array}{c}\mathrm{n}=40 \text { (Swiss strain mice); } 8 \mathrm{wk} ; 4 \text { groups: } \\
\text { standard diet, HFD+YM } 1.0 \mathrm{~g} / \mathrm{kg}, 2.0 \mathrm{~g} / \mathrm{kg} \text {, } \\
\text { HFD+water }\end{array}$ & $\begin{array}{l}1.0 \text { or } 2.0 \mathrm{~g} / \mathrm{kg} \\
\text { Instant YM by } \\
\text { intragastric gavage }\end{array}$ & $\begin{array}{l}\text { 348.8 } \pm 16.35 \mathrm{mg} / \mathrm{g} \\
\text { (5-CQA units) }\end{array}$ & $\begin{array}{l}\downarrow \text { TG, LDL-c, liver lipid } \\
\text { content; suppression of } \\
\text { weight gain without } \\
\text { affecting energy intake } \\
\text { (HFD vs. HFD+YM) }\end{array}$ & $\begin{array}{l}\text { Anti-obesity and } \\
\text { hypolipidemic } \\
\text { effects }\end{array}$ \\
\hline $\begin{array}{l}\text { Martins et } \\
\text { al (2009) }\end{array}$ & $\begin{array}{c}\mathrm{n}=40 \text { (Swiss strain mice); } \\
8 \text { wk; } 4 \text { groups: water, } 0.5 \mathrm{~g} / \mathrm{kg} \mathrm{YM}, 1.0 \mathrm{~g} / \mathrm{kg} \text {, } \\
2.0 \mathrm{~g} / \mathrm{kg}\end{array}$ & $\begin{array}{l}0.5,1.0,2.0 \mathrm{~g} / \mathrm{kg} \\
\text { Instant YM by } \\
\text { intragastric gavage }\end{array}$ & $\begin{array}{l}\text { Total polyphenols } \\
\text { contents } 350.0 \\
\mathrm{mg} / \mathrm{g}\end{array}$ & $\begin{array}{c}\downarrow \text { liver lipid peroxidation; } \\
\uparrow \text { PUFA, MUFA and } \\
\text { PUFA/SFA ratio. No } \\
\text { difference in TC, HDL-c, } \\
\text { and TG }\end{array}$ & $\begin{array}{l}\text { Lipid anti- } \\
\text { peroxidation } \\
\text { effect }\end{array}$ \\
\hline $\begin{array}{l}\text { Arçari et al } \\
(2009)^{36}\end{array}$ & $\begin{array}{l}\mathrm{n}=30 \text { (Swiss strain mice); } 8 \text { wk; } 3 \text { groups: } \\
\text { NC, HFD+water and HFD+1.0 g/kg YM }\end{array}$ & $\begin{array}{l}1.0 \mathrm{~g} / \mathrm{kg} \text { Instant } \\
\text { Mate by } \\
\text { intragastric gavage }\end{array}$ & $\begin{array}{c}\text { Total polyphenols } \\
\text { contents } \\
348.80 \pm 16.35 \\
\mathrm{mg} / \mathrm{g}\end{array}$ & $\begin{array}{l}\text { Suppression of weight } \\
\text { gain; } \downarrow \text { in epididymal fat } \\
\text { pad weight, TC, LDL-c, } \\
\text { TG, and glucose in } \\
\text { HFD+YM compared to } \\
\text { HFD; modulatory effect on } \\
\text { genes related to obesity }\end{array}$ & $\begin{array}{l}\text { Anti-obesity } \\
\text { effect }\end{array}$ \\
\hline Lanzetti et & $\mathrm{n}=40$ (C57BL/6 male mice); & $150.0 \mathrm{mg} / \mathrm{kg}$ & Unknown & $\downarrow$ alveolar macrophages & Hypolipidemic \\
\hline
\end{tabular}




\begin{tabular}{|c|c|c|c|c|c|}
\hline $\begin{array}{c}a l \\
(2008)^{26}\end{array}$ & $\begin{array}{c}5 \text { days; } 4 \text { groups: control, YM oral } \\
\text { gavage+smoke, water oral gavage+smoke, } \\
\text { YM intraperitonially +smoke }\end{array}$ & $\begin{array}{l}\text { intraperitoneally or } \\
\text { by oral gavage; } \\
10.0 \mathrm{~g} \text { of dry } \\
\text { leaves in } 200 \mathrm{~mL} \\
\text { boiling water }\end{array}$ & & $\begin{array}{l}\text { and neutrophils in } \\
\text { bronchoalveolar gavages } \\
\text { and } \downarrow \text { lipid peroxidation, } \\
\text { TNF- } \alpha \text {, and matrix mallo- } \\
\text { protease } 9 \text { activity in YM } \\
\text { (oral)+smoke group }\end{array}$ & $\begin{array}{l}\text { and anti- } \\
\text { inflammatory } \\
\text { effect }\end{array}$ \\
\hline $\begin{array}{l}\text { Pang et al } \\
(2008)^{34}\end{array}$ & $\begin{array}{l}\mathrm{n}=24 \text { (Sprague-Dawley rats); } 60 \text { days; } 3 \\
\text { groups: control, HFD, HFD+YM) }\end{array}$ & $\begin{array}{l}2.4 \mathrm{~g} / \mathrm{kg} \text { Alcoholic } \\
\text { extract }(15 \%) \\
\text { combined with } \\
\text { food pellets }\end{array}$ & $\begin{array}{l}\text { 24-30\%, 5-CQA; } \\
\text { 2-4\%, caffeine }\end{array}$ & $\begin{array}{l}\text { Suppression of weight } \\
\text { gain; } \downarrow \text { visceral fat pad } \\
\text { weight, TG, LDL-c, } \\
\text { hepatic TG and TG for } \\
\text { HFD+YM; } \downarrow \text { food intake } \\
\text { in HFD+YM. }\end{array}$ & $\begin{array}{l}\text { Anti-obesity and } \\
\text { hypolipidemic } \\
\text { effect }\end{array}$ \\
\hline $\begin{array}{l}\text { Oliveira et } \\
\text { al (2008) }\end{array}$ & $\begin{array}{l}\mathrm{n}=41(\text { Wistar rats }) ; 28 \text { days } \\
4 \text { groups: NDC }(\mathrm{n}=10), \mathrm{ND}+\mathrm{YM}(\mathrm{n}=10), \mathrm{DC} \\
(\mathrm{n}=11), \mathrm{DC}+\mathrm{YM}(\mathrm{n}=10)\end{array}$ & $\begin{array}{l}1.0 \mathrm{~g} / \mathrm{kg} \text { Instant } \\
\text { Mate by } \\
\text { intragastric gavage }\end{array}$ & $\begin{array}{l}420.0 \mathrm{mg} / \mathrm{g}(5- \\
\text { CQA units) }\end{array}$ & $\begin{array}{l}\text { Intestinal SGLT1 gene } \\
\text { expression lower in the } \\
\text { YM groups both in upper } \\
\text { and middle small intestine; } \\
\text { YM appears to affect } \\
\text { glucose absorption }\end{array}$ & $\begin{array}{l}\text { Possible anti- } \\
\text { diabetic effect }\end{array}$ \\
\hline $\begin{array}{l}\text { Mosimann } \\
\text { et al (2006) } \\
\qquad 14\end{array}$ & $\begin{array}{c}\mathrm{n}=32 \text { (Zealand White male rabbits); } 2 \text { months } \\
4 \text { groups: control }(\mathrm{n}=5) \text {, control+YM }(\mathrm{n}=5) \text {, } \\
\text { HC diet }(\mathrm{n}=11) \text {, HC diet+YM }(\mathrm{n}=11)\end{array}$ & $\begin{array}{c}50.0 \mathrm{mg} / \mathrm{mL} \text { leaves } \\
\text { at boiling water; } \\
390.0 \mathrm{~mL} / \text { day } \\
\text { drunk instead of } \\
\text { water } \\
\end{array}$ & $\begin{array}{c}\text { Total polyphenols } \\
\text { contents } 4.89 \pm .42 \\
\mathrm{mg} / \mathrm{mL}\end{array}$ & $\begin{array}{l}\text { Smaller atherosclerotic } \\
\text { lesions in HC diet+YM } \\
\text { compared to HC diet }\end{array}$ & $\begin{array}{c}\downarrow \text { of } \\
\text { atherosclerosis; } \\
\text { no hypolipidemic } \\
\text { effect }\end{array}$ \\
\hline $\begin{array}{l}\text { Paganini et } \\
\text { al }(2005)^{25}\end{array}$ & $\begin{array}{c}\mathrm{n}=36 \text { (Wistar rats); } \\
15 \text { days; } 3 \text { groups: normal diet, HCD, } \\
\text { HCD+YM }\end{array}$ & $\begin{array}{l}110.0 \mathrm{~g} \text { of } \mathrm{YM} \text { in } \\
\text { in } 1 \mathrm{~L} \text { of } 80^{\circ} \mathrm{C} \\
500.0 \mathrm{mg} / \mathrm{kg} \mathrm{YM} \\
\text { by intragastric } \\
\text { gavage }\end{array}$ & Unknown & $\begin{array}{l}\text { YM+HC diet led to } \\
\text { reduction in TC and TG } \\
\text { compared to HCD }\end{array}$ & $\begin{array}{l}\text { Hypolipidemic } \\
\text { effect }\end{array}$ \\
\hline
\end{tabular}

Notes: YM, yerba mate; SW, standard water; SM, standard mate; HW, high-cholesterol water; HM, high-cholesterol mate; TG, triglycerides; LDL-c, low density lipoprotein cholesterol; MDA, malondialdehyde; HDL-c, high density lipoprotein cholesterol; NC, normal control group; HFD, high fat diet; Chlorogenic acid, CGA, TNF- $\alpha$, tumor necrosis factor alpha; LPL, lipoprotein lipase; HL, hepatic lipase; TXB2, thromboxane B2; NO, nitric oxide; 6keto-PGF1 $\alpha$, 6-keto prostaglandin F1 $\alpha$; ICAM-1, intercellular adhesion molecule-1; LDLR, low density lipoprotein receptor; SR-B1, scavenger receptor B1; LAE, Leaf aqueous extract; FHE, Hydroethanolic extract from unripe fruits; MSF, Purified mate saponin fraction; TSNO, Tsumura Suzuki nonobese; TSOD, Tsumura Suzuki obese diabetic; NEFAs, non-esterified fatty acids; TC, total cholesterol; IR, insulin resistance; CW, water group; CM, commercial yerba mate group; GM, gross mate group; 5-CQA, 5-Caffeoylquinic acid; PUFA, polyunsaturated fatty acids; MUFA, monounsaturated fatty acids; SFA, saturated fatty acids; NDC, non-diabetic control; ND, non-diabetic; DC, diabetic control; SGLT1, sodium-glucose linked transporter; HCD, high cholesterol diet.

Table 3. In vivo effect of Yerba Mate on potential risk factors for cardiovascular diseases in humans

\begin{tabular}{|c|c|c|c|c|c|}
\hline References & $\begin{array}{c}\text { Sample, period and type of } \\
\text { intervention }\end{array}$ & Preparation of YM & $\begin{array}{c}\text { Active } \\
\text { compounds }\end{array}$ & Main findings & Conclusions \\
\hline $\begin{array}{l}\text { Klein et al } \\
(2011)^{52}\end{array}$ & $\begin{array}{c}\mathrm{n}=58 \text { (29, T2DM and } 29 \text { pre- } \\
\text { diabetes); } 3 \text { groups: YM, DI, } \\
\text { and YM+DI. Parameters at } \\
\text { baseline and after } 20,40 \text {, and } \\
60 \text { days }\end{array}$ & $\begin{array}{l}330 \mathrm{~mL} \text { of roasted YM } 3 \text { times } \\
\text { a day and/or received nutritional } \\
\text { counseling over } 60 \text { days }\end{array}$ & unknown & $\begin{array}{c}\downarrow \text { fasting glucose, HbA } \\
\text { (1c), LDL-c of T2DM } \\
\text { subjects. In pre-diabetes } \\
\text { YM+nutritional } \\
\text { counseling } \downarrow \text { LDL-c, } \\
\text { non-HDL-c, and TG }\end{array}$ & $\begin{array}{l}\text { Improved the } \\
\text { glycemic control and } \\
\text { lipid profile of } \\
\text { T2DM subjects }\end{array}$ \\
\hline $\begin{array}{l}\text { Matsumoto } \\
\text { et al (2009) }\end{array}$ & $\begin{array}{c}\mathrm{n}=15 \text {; healthy young women; } \\
\text { blood collected before and } \\
\text { after } 1 \mathrm{~h} \text { and } 7 \text { days }\end{array}$ & $\begin{array}{l}5.0 \mathrm{~g} \text { Instant Mate in } 500.0 \mathrm{~mL} \\
\text { of fresh water/ once a day }\end{array}$ & $\begin{array}{l}350.0 \mathrm{mg} / \mathrm{g}(5- \\
\text { CQA units) }\end{array}$ & $\begin{array}{l}\downarrow \text { ex vivo } \mathrm{CuSO}_{4} \text { serum } \\
\text { lipid peroxidation; } \uparrow \text { in } \\
\text { antioxidant status and } \\
\text { antioxidant enzyme gene } \\
\text { expression }\end{array}$ & Antioxidant effects \\
\hline $\begin{array}{l}\text { de Morais } \\
\text { et al (2009) } \\
38\end{array}$ & $\begin{array}{l}\mathrm{n}=102 ; 20 \text { and } 40 \text { days Data } \\
\text { before and after YM; } 3 \text { groups: } \\
\mathrm{NC},(\mathrm{n}=15) \text {, dyslipidemic } \\
(\mathrm{n}=57) \text {, hypercholesterolemic } \\
\text { on statin therapy }(\mathrm{n}=30)\end{array}$ & $\begin{array}{l}\text { Dried leaves in boiling water for } \\
10 \text { minutes at } 50.0 \mathrm{mg} / \mathrm{mL} \\
\text { (green) and } 20.0 \mathrm{mg} / \mathrm{mL} \\
\text { (roasted); } 330 \mathrm{~mL} / 3 \mathrm{x} \text { day }\end{array}$ & $\begin{array}{c}\text { Green }(5.51 \\
\mathrm{mg} / \mathrm{mL}) ; \text { roasted } \\
(1.74 \mathrm{mg} / \mathrm{mL}) \\
\text { (CGA } \\
\text { equivalents) }\end{array}$ & $\begin{array}{c}\downarrow \text { LDL-c in all subjects } \\
\text { after } 20 \text { and } 40 \text { days; } \uparrow \\
\text { HDL-c for individuals on } \\
\text { statin therapy after } \\
\text { 40days; } \downarrow \text { SBP for all } \\
\text { subjects after } 40 \text { days }\end{array}$ & $\begin{array}{l}\text { Hypolipidemic } \\
\text { effect; reduction of } \\
\text { SBP }\end{array}$ \\
\hline $\begin{array}{l}\text { Silva et al } \\
(2008)^{18}\end{array}$ & $\begin{array}{l}\mathrm{n}=12 \text {; healthy volunteers; } \\
\text { blood collected before and } \\
\text { after } 1 \text { h of YM intake }\end{array}$ & $\begin{array}{c}\text { Commercial YM in boiling } \\
\text { water for } 10 \text { minutes at } 50.0 \\
\mathrm{mg} / \mathrm{mL}\end{array}$ & $\begin{array}{l}2.93 \pm 0.12 \mathrm{mg} / \mathrm{mL} \\
\text { total polyphenol } \\
\text { content }\end{array}$ & $\begin{array}{c}\text { Lower LDL plasma } \\
\text { oxidation susceptibility } \\
\text { and increased antioxidant } \\
\text { plasma capacity } \\
\end{array}$ & Antioxidant effects \\
\hline $\begin{array}{l}\text { Menini et al } \\
\quad(2007)^{20}\end{array}$ & $\begin{array}{l}\mathrm{n}=4 \text {; healthy volunteers; } \\
\text { blood collected before and } \\
\text { after } 1 \mathrm{~h} \text { of YM intake }\end{array}$ & $\begin{array}{c}500.0 \mathrm{~mL} \text { warm water }\left(80^{\circ} \mathrm{C}\right) \\
\text { added slowly multiple times to } \\
50.0 \mathrm{~g} \text { dried minced leaves }\end{array}$ & $\begin{array}{c}3.4 \pm 0.1 \mathrm{mg} / \mathrm{mL} \\
\text { total polyphenols } \\
\text { (CGA } \\
\text { equivalents) }\end{array}$ & $\begin{array}{c}\text { Acute increase in } \\
\text { paraoxonase } 1 \text { activity } 1 \\
\text { h after YM consumption }\end{array}$ & Antioxidant effects \\
\hline $\begin{array}{l}\text { Andersen } \\
\text { and Fogh } \\
(2001)^{46}\end{array}$ & $\begin{array}{l}\text { 1) } n=7 \text {; healthy normal weigh } \\
\text { volunteers; } \\
\text { 2) } n=44 \text {; overweight patients } \\
\text { ( } 10 \text { and } 45 \text { days; } 3) n=22 ; \\
\text { weight maintenance over } 12 \\
\text { months. }\end{array}$ & $\begin{array}{c}\text { YGD }(\mathrm{YM}=112 \mathrm{mg}+ \\
\text { Guarana=95 mg+Damiana = } 36 \\
\text { mg }) \text { capsules. }\end{array}$ & $\begin{array}{c}\text { YM }(1 \pm 1.5 \% \\
\text { caffeine, } 4 \pm 10 \% \\
\text { tannins); Guarana } \\
\text { ( } 3 \pm 6 \% \text { caffeine, } \\
5 \pm 8.5 \% \text { tannins, } \\
0.06 \% \text { saponin); } \\
\text { Damiana } \\
\text { (tannins) }\end{array}$ & $\begin{array}{l}\text { YGD prolonged gastric } \\
\text { emptying time; Body } \\
\text { weight reduced } 0.8 \pm 0.05 \\
\text { kg after } 10 \text { days and } 5.1 \pm \\
0.5 \text { kg after } 45 \text { days }\end{array}$ & $\begin{array}{c}\text { Induced weight loss } \\
\text { over } 45 \text { days in } \\
\text { overweight patients } \\
\text { treated in a primary } \\
\text { health care context }\end{array}$ \\
\hline
\end{tabular}

Notes: YM, yerba mate; T2DM, type-2 diabetes mellitus; DI, dietary intervention; HbA(1c), glycated hemoglobin; LDL-c, low density lipoprotein cholesterol; HDL-c, high density lipoprotein cholesterol; 5-CQA, 5-Caffeoylquinic acid; Chlorogenic acid, CGA; SBP, systolic blood pressure; NC, normal control group; YGD, Yerba Mate+Guarana+Damiana. 
Our search identified 226 and 132 articles at PubMed and FSTA, respectively. However, 71 of them were cited in both databases. Therefore, 61 articles were considered from FSTA. Given that only one (1) article was obtained when the descriptors I. paraguariensis and cardio* were utilized in the search, the authors decided to read the 287 articles found in PubMed and FSTA databases. From those, 22 articles were eligible because they assessed the associations between I. paraguariensis, yerba mate (or its main compounds) and the following risk factors for CVDs: oxidative stress, atherosclerosis, dyslipidemia, overweight/obesity and T2DM. Table 2 (animal studies) and Table 3 (human studies) summarize the results of the clinical trials selected.

\section{Yerba Mate and Oxidative Stress}

Water extracts of YM are known to contain high levels of phenolic compounds [4,10]. These extracts have high antioxidant activity in vitro, ex vivo, and in vivo. YM has been shown to reduce in vitro lipid and lipoprotein oxidation.

\subsection{Animal Studies}

Incubation of rat microsomes with YM prevented lipid oxidation by the non-enzymatic $\mathrm{Fe}^{2+}$ /ascorbate system and by the enzymatic $\mathrm{Cl}_{4} \mathrm{C} / \mathrm{NADPH}$ system in a dosedependent manner. In addition, $\mathrm{YM}$ also prevented lipid peroxidation by $\mathrm{H}_{2} \mathrm{O}_{2}$ in red blood cells, acting as an effective scavenger of superoxide anion [12].

Antioxidant effects ex vivo have been found in animal studies. YM extract intake by rats $(0.5,1.0$, or $2.0 \mathrm{~g}$ $\mathrm{YM} / \mathrm{kg} /$ day; $350 \mathrm{mg}$ phenolics/g YM) for 2 months reduced ex vivo $\mathrm{H}_{2} \mathrm{O}_{2}$-induced DNA damage in liver cells and improved ex vivo DNA repair after $\mathrm{H}_{2} \mathrm{O}_{2}$-induced damage [13].

In vivo animal studies show inconsistent results concerning the antioxidant effects of YM. Rabbits fed YM extract (1.2 g polyphenols/day) for two months $(n=5)$ did not show changes in the activity of the antioxidant enzymes superoxide dismutase, glutathione peroxidase or catalase compared to rabbits in the control group $(n=5)$. Rabbits fed YM extract in conjunction with a hypercholesterolemic diet (HCD) for two months $(n=10)$ displayed lower glutathione peroxidase activity compared to rabbits fed only the HCD $(n=10)$. The HCD alone increased activity of the antioxidant enzymes compared to the control group. Furthermore, consumption of YM extract did not affect lipid peroxidation in neither group [14]. However, rats fed YM extract $(0.5,1.0$, or $2.0 \mathrm{~g}$ instant tea $/ \mathrm{kg} /$ day; $350.0 \mathrm{mg} / \mathrm{g}$ total phenolic) for 60 consecutive days displayed reduced liver lipid peroxidation [15]. The apparent contradictory nature of these findings may be due to the differences in study design, the measurements selected to represent antioxidant effects (mRNA expression, antioxidant enzyme activity, lipid peroxidation) and the analyzed target tissues.

\subsection{Human Studies}

YM also prevents oxidation of human plasma lipids in vitro. Incubation of human serum with $40.2 \mu \mathrm{g} / \mathrm{mL}$ of YM extract $(12.5 \mu \mathrm{g} / \mathrm{mL}$ total phenol) prevented copper- induced lipid peroxidation during incubation at $100 \mathrm{uM}$ $\mathrm{CuCl}_{2}$ for $5 \mathrm{~h}$, as measured by thiobarbituric acid reactive substance formation. Incubation with $16 \mu \mathrm{g} / \mathrm{mL}$ of $\mathrm{YM}$ extract ( $5 \mu \mathrm{g} / \mathrm{mL}$ total phenol) inhibited lipid peroxidation for $3 \mathrm{~h}$ of incubation, after which thiobarbituric acid reactive substance levels increased linearly. This indicates that the antioxidant compounds of the YM extract were consumed during lipid peroxidation [14].

Bracesco et al. [4] have observed that incubation of human low density lipoprotein cholesterol (LDL-c) with $1-20 \mu \mathrm{g} / \mathrm{mL}$ of $\mathrm{YM}$ extract $(6.5 \mu \mathrm{mol} / \mathrm{L}$ total phenol, quercetin equivalents) prevented lipoxygenase-induced and peroxynitrite-induced oxidation.

As noted previously, antioxidant compounds found in high levels of YM are chlorogenic and caffeic acids [11]. Incubation of chlorogenic acid with human LDL-c prevented oxidation by ferrylmyoglobin. Similar results were found with caffeic acid [16]. Incubation with 5-CQA, a chlorogenic acid, was also found to prevent hypochlorite-induced oxidative damage to the antioxidant enzyme paraxonase-1 found in high density lipoprotein cholesterol (HDL-c) [17].

The experiment conducted by Silva et al. [18] demonstrated that acute intake of $500 \mathrm{~mL}$ of YM beverage $(2.93 \pm 0.12 \mathrm{mg} / \mathrm{dL}$ total phenol content) resulted in significantly lower $(\mathrm{p}<0.05)$ susceptibility to copper-ion or amidine-propane-hydrochloride-induced lipid peroxidation. Furthermore, $1 \mathrm{~h}$ after YM intake, plasma antioxidant capacity had a $7.7 \%$ enhancement $(\mathrm{p}<0.05)$.

The authors also tested the effect of isolated YM compounds on copper ion-induced LDL-c oxidation, and found a dose-dependent inhibition of YM compounds. However, the YM extract appeared to have a higher antioxidant activity at the same phenol equivalent concentration than the isolated compounds, indicating a possible synergic effect of the phenols. These results suggest the role of phenolic compounds in causing the antioxidant effects of YM.

In healthy human subjects, both acute and chronic YM intake reduced ex vivo $\mathrm{CuSO}_{4}$ oxidation of plasma lipids. In healthy individuals $(n=3)$, copper-induced oxidation of LDL-C was reduced $1 \mathrm{~h}$ after intake of $500 \mathrm{~mL}$ YM beverage [19]. In healthy young women $(n=15)$, copperinduced oxidation of plasma lipids was reduced by $17 \%$ 1h after intake, compared to baseline, and reduced by $37 \%$ after chronic intake for seven days, using $500 \mathrm{~mL} /$ day of YM (1.75 g/day phenolic compounds). The authors reported that, in this population, ingestion of this dose showed to increase serum antioxidant capacity and mRNA expression of superoxide dismutase, glutathione peroxidase and catalase [6].

Acute YM intake (500 mL, 1.7 g phenolic compounds) has also been shown to increase in vivo activity of paraxonase-1 in healthy volunteers $(n=4)$. One hour after YM intake, paraxonase-1 activity increased $10 \%$ relative to baseline. Paraxonase- 1 is an antioxidant enzyme associated with HDL-c that may prevent oxidation of LDL-c [20].

Current data on YM clearly demonstrate its antioxidant effects in vitro and in vivo. This high antioxidant capacity is attributed and is directly proportional to its high polyphenol concentration, namely, the caffeoyl derivatives [3]. The effects of YM intake may have implications for CVDs, since oxidative stress, and particularly oxidation of 
LDL-c, has been involved in the progression of CVDs [21].

\section{Yerba Mate and Atherosclerosis}

Endothelial dysfunction precedes clinical cardiovascular disease and atherosclerosis, leading to vasoconstriction, inflammation and macrophage adhesion, smooth muscle cell proliferation, immune system activation, and coronary artery thrombus formation [22]. It is of interest to determine whether natural products such as YM can benefit endothelial function and therefore prevent cardiovascular events.

\subsection{Animal Studies}

Ex vivo studies on rat mesenteric arterial beds have found that YM exerts an endothelium dependent vasorelaxing activity, most likely through a nitric oxidedependent mechanism [23]. YM extract also improved post-ischemic recovery of isolated rat hearts through a nitric oxide-dependent pathway [24]. However, the vasodilatory effects of YM were inhibited when rats consumed a HCD [25].

Rabbits fed HCD+YM showed a smaller atherosclerotic lesion area compared to rabbits fed a HCD only (35.4\% vs. $60.1 \%, \mathrm{p}<0.05)$ [14]. This result may be due to the antiinflammatory effects of YM, which has been demonstrated in mice by reducing acute lung inflammation after cigarette exposure [26]. Saponins and quercetin have also been shown to reduce the inflammatory response in macrophages [27]. Macrophage activation is important in the pathogenesis of atherosclerosis.

Gao et al. [28] investigated the effect of YM on vascular endothelial dysfunction and liver lipoprotein receptor gene expression in hyperlipidemic rats. The animals were randomly divided into five groups: a normal control group (NC), a high-fat diet group (HC), and three YM-treated groups (1\%, $2 \%$ and $4 \%$ of YM). The results were significant, indicating that YM reduced endothelin and thromboxane B2 (TXB2) levels and increased nitric oxide and 6-keto prostaglandin F1 $\alpha$ (6-keto-PGF1 $\alpha$ ) levels in the blood, reduced the pathological damage of vascular endothelial cells, decreased intercellular adhesion molecule-1 protein expression, and up-regulated mRNA expression of hepatic low density lipoprotein receptor (LDLR) and scavenger receptor B1 (SR-B1). This mechanism may be involved in reducing the incidence of atherosclerosis

\subsection{Human Studies}

Few studies have examined the effect of YM on endothelial function, and as far as we know there is no study in humans. Even though these studies have demonstrated that YM extracts exert an effect on the endothelium of animals, clinical trials in humans are needed to assess the effect of YM extracts on vascular endothelium.

\section{Yerba Mate and Dyslipidemia}

Hypercholesterolemia is one of the many factors involved in the etiology of CVDs due to high levels of LDL-c and low levels of HDL-c [29]. It is well-known that the pathological processes related to CVDs can be minimized by reducing plasma LDL-c and/or increasing HDL-c [30,31]. Studies have shown that intake of YM may help improve the lipid profile, and thus reduce risk of CVDs.

\subsection{Animal Studies}

Some studies have shown that YM intake can have hypolipidemic effects in rats. Recently, Bravo et al. [32] studying the effect of YM on serum lipids and antioxidant status of normocholesterolemic and hypercholesterolemic rats demonstrated that in normocholesterolemic animals, YM had no effect on serum lipids or antioxidant status. Although in hypercholesterolemic rats, YM consumption had no effect on HDL-c or protein carbonyls, it showed a marked hypolipidemic action, decreasing TG, total and LDL-c, and serum malonaldehyde levels. These parameters had been increased after consuming a highcholesterol diet pointing out that the potential beneficial effect of YM on markers of cardiovascular risk seems to be restricted to hyperlipidemic animals.

Gao et al. [33], with the same experimental model used in a previous study [28], but studying hyperlipidemic Syrian golden hamsters, evaluated the effects of YM aqueous extract on body weight, serum lipids, antioxidant enzyme activity, lipoprotein metabolism enzyme activity, and gene expression involved in lipid metabolism of these animals. The results indicate that YM improvement hyperlipidemia, in part, by reducing lipid peroxidation, improving endothelial function and lipoprotein lipase and hepatic lipase activities, and modulating the expression levels of genes involved in lipid oxidation and lipogenesis.

This effect has been demonstrated by Paganini et al. [25] in an experimental study with rats $(n=36)$ divided into three groups: control, HCD, and HCD treated with YM extract. A HCD was administered for 30 days to increase cholesterol and TG plasma levels; after 30 days the HCD+YM group received for 15 days $500 \mathrm{mg} / \mathrm{kg}$ of YM extract. The rats in the HCD+YM group had significantly reduced levels of total cholesterol (TC) and TG compared to the HCD group, but the levels were still significantly increased over those of the standard diet rats.

A similar hypolipidemic effect of YM extract was found in rats and mice fed high-fat diets (HFD). Pang et al. [34] conducted a study with rats separated into three groups: control diet, HFD alone, and HFD with YM alcohol extract treatment (24-30\% caffeoylquinic acids, 2$4 \%$ caffeine, $0.3-1.2 \%$ theobromine, and $>1.0 \%$ triterpenic saponins). The authors observed that plasma TG, VLDL and LDL-c concentrations of the rats fed the HFD+YM were $30 \%$ and $36 \%$ lower than the rats of the HFD group and the control ( $\mathrm{p}<0.05)$, respectively. The HFD-induced elevation in the plasma free fatty acid concentrations was reversed when the rats were fed with YM extract (31\% reduction, $\mathrm{p}<0.05)$. In addition, the hepatic enlargement and accumulations of TG and cholesterol, induced by the HFD, were significantly ameliorated by dietary supplementation with YM extract (9.3\% reduction in liver weight, $\mathrm{p}<0.05 ; 21 \%$ reduction in their hepatic TG level; and $41 \%$ reduction in hepatic cholesterol level, $\mathrm{p}<0.05$ ). 
Martins et al. [35] conducted an experiment involving mice, which showed similar results to Pang et al. [34] Mice were fed a standard diet $(n=10)$ or HFD $(n=30)$ for 16 weeks. After eight weeks on the HFD, the obesity status was observed, and the animals were randomly divided into three subgroups according to the intervention: group $1(n=10)$ and group $2(n=10)$ received an aqueous extract of YM in different doses $(1 \mathrm{~g} / \mathrm{kg}$ and $2 \mathrm{~g} / \mathrm{kg}$ of body weight respectively; $350.0 \mathrm{mg} / \mathrm{g}$ total phenolics), while group 3 (control group) $(n=10)$ received pure water. YM decreased serum TG and LDL-c at both doses after they had been increased by the HFD. The liver lipid content was also decreased by the diet containing YM.

Another study with mice found similar results [36]. Mice were introduced to a HFD $(n=20)$ for 16 weeks. After the first 8 weeks on a HFD the obesity status was observed and the animals were randomly divided into two subgroups: group $1(\mathrm{n}=10)$ received an aqueous extract of roasted YM extract $(1.0 \mathrm{mg} / \mathrm{kg} ; 348.8 \mathrm{mg} / \mathrm{g}$ total phenolics) and group $2(n=10)$ received pure water for 8 weeks. Group 1 showed a decrease in serum levels of cholesterol, TG and LDL-c when compared to group 2.

However, there are studies where an association between YM extract intake and lipid profile was not found. In rabbits, HCD+YM did not lead to differences in lipid profile and hepatic cholesterol content compared to HCD after two months [14]. YM intake (420.0mg/g 5caffeolylquinic acid units) for 28 days did not affect TC in alloxan-induced diabetic rats [37].

\subsection{Human Studies}

de Morais et al. [38] developed a single-blind controlled trial study with humans to verify the effect of YM consumption on lipid profile. One hundred and two subjects were divided into groups: normolipidemic $(n=15)$, dyslipidemic $(n=57)$, and hypercholesterolemic subjects on long-term statin therapy $(n=30)$. The subjects ingested $330 \mathrm{~mL}$ of YM infusions, three times a day for 20 and 40 days. In normolipidemic subjects, YM consumption reduced LDL-c by $8.7 \%$ ( $p<0.05$ ) after 20 days of YM intake. Compared with the baseline period, YM intake by dyslipidemic individuals for 20 and 40 days lowered LDL-c by 8.1 and $8.6 \%$ (p < 0.001), and non-HDL-c by 5.4 and $6.5 \%(\mathrm{p}<0.001)$, respectively. After 20 days of YM intake, HDL-c was increased by $4.4 \%$ (p < 0.001). Finally, the consumption of YM by hypercholesterolemic individuals on statin therapy promoted additional 10.0\% and $13.1 \%$ reductions in LDL-c after 20 and 40 days respectively ( $p<0.001$ ), and increased HDL-c by $6.2 \%$ after 40 days $(\mathrm{p}<0.05)$. In all participants TG levels remained unchanged.

These effects on lipid profile may be due to saponins that remain in the gastrointestinal tract, and interact with cholesterol and bile acids producing complexes that prevent their absorption [39,40,41,42]. The leaves of YM are saponin-rich; therefore, an aqueous extract of its leaves may have potential lipid lowering effects. However, other phenolic compounds may also play a role in producing the hypocholesterolemic effect of YM $[43,44]$.

\section{Yerba Mate and Overweight/obesity}

Overweight (body mass index-BMI in the interval 25$\left.30 \mathrm{~kg} / \mathrm{m}^{2}\right)$ and obesity $\left(\mathrm{BMI}>30 \mathrm{~kg} / \mathrm{m}^{2}\right)$ are risk factors for CVDs [1]. YM intake has been shown in animal studies to be useful in weight reduction, which may lead to cardiovascular benefits.

\subsection{Animal Studies}

Animal studies have shown that YM consumption is effective in weight gain suppression in animals with a HFD. Rats that consumed HFD + YM (2.4g/kg chow; $24 \%$ caffeoylquinic acids) for 60 days $(n=8)$ gained $10.7 \%$ less weight compared to rats consuming HFD alone during the same period $(n=8)$. This reduction in weight gain may be attributed in part to a $4.32 \%$ reduction in food consumption by rats in the HFD+YM group compared to the HFD group. Furthermore, HFD+YM intake reduced weight of total visceral fat-deposits by $16.5 \%$ compared to the HFD group [34]. Similar results were found in two studies in mice. After an eight week-period preparation with HFD only, mice were given HFD+YM (348.8 mg total phenolics/g) or HFD+water daily for more eight weeks by intragastric gavage. Mice receiving HFD+YM (1 g/kg) ( $\mathrm{n}=10)$ reduced body weight compared to rats consuming HFD+water $(n=10)$, with no changes in energy intake. Epididymal fat-pad weight was reduced in the group receiving $\mathrm{HFD}+\mathrm{YM}$ compared to the HFD+water group [36]. In a study with an identical design, mice receiving $1 \mathrm{~g} / \mathrm{kg}$ or $2 \mathrm{~g} / \mathrm{kg}(\mathrm{n}=20) \mathrm{YM}+\mathrm{HFD}$ gained less weight compared to the mice that received a HFD only $(n=10)$, without alterations in energy intake [35]. These results suggest that YM intake may be valuable in weight loss, but further research is required to understand the mechanism by which YM exerts these effects and to confirm these results in humans.

The effect of YM on the intra-abdominal and epididymal fat, and glucose oxidation was studied by Resende et al. [45], for one month, 24 male rats were divided into four groups and following treatments: group A - crude extract from mate leaves ad libitum (24.7 mg of dried residue/mL); group B - $500 \mathrm{mg} / \mathrm{mL}$ of hydroethanolic extract from unripe fruits ad libitum; group C - $500 \mathrm{mg} / \mathrm{mL}$ of chemically well-defined purified saponin fraction ad libitum and group D or negative control group - animals received only water. No significant effect on body weight gain was observed in all groups evaluated after 30-day treatment. Therefore, it seems possible that YM extracts can elicit differentiated effects, depending on whether animals have been induced to obesity previously or not, as earlier suggested.

\subsection{Human Studies}

In humans, YM combined with Guarana (Paullinia cupana) and Damiana (Turnera diffusa) was found to delay gastric emptying and help in weight loss [46]. However, no human studies have specifically investigated the effect of YM intake alone on weight loss and overweight/obesity status.

\section{Yerba Mate and Diabetes}

Chlorogenic acid, the main polyphenol in YM, has been reported to modulate the activity of glucose-6-phosphatase, 
which is involved in glucose metabolism, reducing the risk of CVDs. Mounting evidence suggests that dietary polyphenols may modulate glucose absorption and metabolism. However it is not clear in the literature the mechanisms involved in the short and long-term effects of YM in ameliorating the hyperglycemic status.

\subsection{Animal Studies}

Oliveira et al. [37] studied diabetes in rats, and did not show significant differences in serum glucose, insulin, and hepatic glucose-6-phosphatase activity between the groups that ingested YM and the controls. Animals $(n=41)$ were divided in four groups: nondiabetic control $(n=10)$, nondiabetic YM $(n=10)$, diabetic control $(n=11)$, and diabetic YM $(n=10)$. The intervention consisted in a $1 \mathrm{~g}$ YM extract/kg body weight dose for 28 days; controls received saline solution only. There were no differences in serum glucose, insulin, and hepatic glucose-6-phosphatase activity between the groups. However, the intestinal sodium-glucose linked transporter (SGLT1) gene expression was significantly lower in animals that received YM both in upper $(\mathrm{p}=0.007)$ and middle $(\mathrm{p}<$ 0.001 ) small intestine. These results indicate that bioactive compounds present in YM might be capable of interfering in glucose absorption, by decreasing SGLT1 expression.

In order to investigate hyperglycemia and hypertension associated with T2DM, Ranilla et al. [47] assessed YM in vitro model. The authors showed that YM which had the highest total phenolic contents and antioxidant activity, had moderate $\alpha$-glucosidase inhibitory activity and did not have effect on $\alpha$-amylase and angiotensin I-converting enzyme.

Kang et al. [48] studied anti-obesity and anti-diabetic effects of YM in mice fed a HFD diet. The authors randomized mice into 5 groups after the first 6 weeks on the high-fat diet, as follows: regular diet group (normal diet), high-fat diet group (HFD, control group), HFD+0.5 g/kg YM (HFD+YM 0.5), HFD+1 g/kg YM (HFD+YM 1.0), and HFD+2 g/kg YM (HFD+YM 2.0). The drugs were diluted in purified water and administered once per day for 4 weeks. Despite the small number of sample, the authors concluded that the effects of YM on lipid metabolism included reductions in serum cholesterol, serum TG, and glucose concentrations. Therefore, YM can potentially be used to treat obesity and diabetes.

Hussein et al. [49] investigated the effects of an aqueous extract of YM in T2DM associated with metabolic syndrome. YM extract was suspended in 5\% Arabic gum solution, and given orally to the rats groups in doses of 50, 100, and $200 \mathrm{mg} / \mathrm{kg}$. The control group was given the corresponding vehicle without YM. Thirty minutes later, sucrose solution (20\%, w/v) was administered in a dose of $5 \mathrm{ml} / \mathrm{kg}$. Equivalent volume of water was given orally instead of sucrose in a normal group. Oral administration of YM $(100 \mathrm{mg} / \mathrm{kg})$ for 7 weeks induced, significant decreases in body weight, BMI, and food intake. It significantly decreased the hyperglycemia by reducing fasting blood glucose level, and increasing glucose uptake in glucose tolerance test. It also showed significant improvement in insulin sensitivity by increasing glucose uptake in insulin tolerance test, increasing quantitative insulin sensitivity check index, and decreasing homeostasis model assessment of insulin resistance index.

Silva et al. [50] analyzed the plasma lipid profile, glucose levels and fat deposits in male rats treated with aqueous extract of gross YM, commercial YM or water. The animals were divided into three groups: control water $(\mathrm{CW})$ group $(\mathrm{n}=5)$ : group of animals treated with standard diet and water ad libitum; gross mate (GM) group $(n=5)$ : group of animals treated with standard diet and aqueous extract of gross $I$. paraguariensis ad libitum and commercial YM (CM) group $(n=5)$ : group of animals treated with standard diet and aqueous extract of $I$. paraguariensis ad libitum for 30 days. The results suggested that gross YM reduces fat more efficiently but produces a greater increase in blood glucose when compared to commercial YM and water groups.

Pereira et al. [51] examined the acute in vivo effect and short-and long-term in vitro effects of samples from native and commercial I. paraguariensis on glucose homeostasis and the potential effect of $I$. paraguariensis on serum insulin secretion. Fasted rats were divided into six groups of six animals each: group I, euglycemic control rats; group II, rats receiving glucose $(4 \mathrm{~g} / \mathrm{kg} ; 8.9 \mathrm{M})$; group III, rats receiving glucose $(4 \mathrm{~g} / \mathrm{kg}$ ) plus ethyl acetate (EtOAc) fraction (100 and $200 \mathrm{mg} / \mathrm{kg}$ ); group IV, rats receiving glucose $(4 \mathrm{~g} / \mathrm{kg})$ plus n-butanol (n-BuOH) fraction (100 and $200 \mathrm{mg} / \mathrm{kg})$; group $\mathrm{V}$, rats receiving glucose $(4 \mathrm{~g} / \mathrm{kg})$ plus aqueous extract of green mate infusion (50, 100 and $200 \mathrm{mg} / \mathrm{ml})$; and group VI, rats receiving glucose $(4 \mathrm{~g} / \mathrm{kg}$ ) plus aqueous extract of roasted mate infusion (50, 100 and $200 \mathrm{mg} / \mathrm{ml}$ ) of $I$. paraguariensis. Despite the absence in literature concerning the mechanisms involved in the short and long-term effects of YM in ameliorating the hyperglycemic status, the authors showed that $I$. paraguariensis has an anti-hyperglycemic potential role able to improve the diabetic status and is probably a source of multiple hypoglycemic compounds.

\subsection{Human Studies}

In a pilot study, Klein et al. [52] evaluated the effects of roasted YM consumption, with or without dietary counseling, on the glycemic and lipid profiles of individuals with T2DM or pre-diabetes.

Twenty-nine T2DM and 29 pre-diabetes subjects were divided into 3 groups: YM, dietary intervention, and YM and dietary intervention. Individuals drank $330 \mathrm{~mL}$ of roasted mate tea 3 times a day and/or received nutritional counseling over 60 days. YM consumption decreased significantly the levels of fasting glucose $(25.0 \mathrm{mg} / \mathrm{dL})$, glycated hemoglobin $\mathrm{A}(1 \mathrm{c})(0.85 \%)$, and LDL-c (13.5 $\mathrm{mg} / \mathrm{dL})$ of T2DM subjects $(\mathrm{p}<0.05)$. The authors concluded that YM consumption improved the glycemic control and lipid profile of T2DM subjects. YM consumption combined with nutritional intervention was highly effective in decreasing serum lipid parameters of pre-diabetes individuals, which may reduce their risk of developing coronary disease.

\section{Conclusion}

YM consumption appears to have antioxidant, vasodilation, cholesterol lowering, anti-obesity and anti- 
diabetic effects probably through its compounds polyphenols, saponins and caffeine.

Though many studies have reported the effectiveness of YM on CVD risk factors, comparison among them should be made carefully, considering that the chemical content of YM extracts differs across the studies. The differences may be related not only to the cultivation system and variety of the plant, but also to the preparation of the beverage, the age of the leaves, and whether they are roasted or green.

More study is hereby required, especially double-blind, randomized prospective clinical trials in humans, in order to understand the effects of YM on CVDs, considering that the true mechanism by which YM compounds exerts its effects is unknown.

\section{Acknowledgements}

We would like to thank the sponsorship of The State of Sao Paulo Research Foundation - FAPESP for their financial support.

\section{Declaration of Interest}

All authors have read and approved the final manuscript. The authors declare no conflict of interest.

\section{List of Abbreviations}

5-CQA, 5-caffeoylquinic acid; 6-keto-PGF1 $\alpha$, 6-keto prostaglandin $\mathrm{F} 1 \alpha$; BMI, Body mass index; CM, Commercial Yerba Mate; CVDs, Cardiovascular diseases; CW, Control water; EtOAc, Ethyl acetate; FSTA, Food Science and Technology Abstracts; GM, Gross mate; HC, High-fat diet group; HCD, high cholesterol diet; HDL-c, High density lipoprotein cholesterol; HFD, High-fat diets; LDL-c, Low density lipoprotein cholesterol; LDLR, Low density lipoprotein receptor; MUFA, monounsaturated fatty acids; n-BuOH, n-butanol; NC, Normal control group; PUFA, polyunsaturated fatty acids; SBP, systolic blood pressure; SFA, saturated fatty acids; SGLT1, Sodium-glucose linked transporter; SR-B1, Scavenger receptor B1; T2DM, Type-2 diabetes mellitus; TC, total cholesterol; TG, triglycerides; TNF- $\alpha$, tumor necrosis factor alpha; TXB2, Thromboxane B2; YGD, Yerba Mate+Guarana+Damiana; YM, Yerba Mate.

\section{References}

[1] World Health Organization-WHO (2009). Cardiovascular Disease. 2009 [Online] Available at: http://www.who.int/cardiovascular_diseases/en. Accessed 20 November 2014.

[2] Spector R, Snapinn SM. Statins for secondary prevention of cardiovascular disease: the right dose. Pharmacology 2011; 87: 63-9.

[3] Heck CI, de Mejia EG. Yerba mate tea (Ilex paraguariensis): a comprehensive review on chemistry, health implications, and technological considerations. Journal of Food Science 2007; 72: R138-51.

[4] Bracesco N, Dell M, Rocha A, Behtash S, Menini T, Gugliucci A, Nunes E. Antioxidant activity of a botanical extract preparation of Ilex paraguariensis: prevention of DNA double-strand breaks in
Saccharomyces cerevisiae and human low-density lipoprotein oxidation. The Journal of Alternative and Complementary Medicine 2003; 9: 379-87.

[5] Vieira MA, Maraschin M, Pagliosa CM, Podestá R, de Simas KN, Rockenbach II, Amboni RD, Amante ER. Phenolic acids and methylxanthines composition and antioxidant properties of mate (Ilex paraguariensis) residue. Journal of Food Science 2010; 75: C280-5.

[6] Matsumoto RL, Bastos DH, Mendonça S, Nunes VS, Bartchewsky W, Ribeiro ML de Oliveira Carvalho P. Effects of mate tea (Ilex paraguariensis) ingestion on mRNA expression of antioxidant enzymes, lipid peroxidation, and total antioxidant status in healthy young women. J Journal of Agricultural and Food Chemistry 2009; 57: 1775-80.

[7] Reginatto FH, Athayde ML, Gosmann G, Schenkel EP. Methylxanthines Accumulation in Ilex Species-Caffeine and Theobromine in Erva-Mate (Ilex paraguariensis) and Other Ilex Species. Journal of the Brazilian Chemical Society 1999; 10: 4436.

[8] Giulian R, Santos CE, Shubeita S de M, Silva LM, Dias JF, Yoneama ML. Elemental characterization of commercial mate tea leaves (Ilex paraguariensis A. St.-Hil.) before and after hot water infusion using ion beam techniques. Journal of Agricultural and Food Chemistry 2007; 55: 741-6.

[9] Coelho GC, Gnoatto SB, Bassani VL, Schenkel EP. Quantification of saponins in extractive solution of mate leaves (Ilex paraguariensis A. St. Hil.). Journal of Medicinal Food 2010; 13: 439-43.

[10] Filip R, López P, Giberti G, Coussio J, Ferraro G. Phenolic compounds in seven South American Ilex species. Fitoterapia. 2001; 72: 774-8.

[11] Bastos DH, Saldanha LA, Catharino RR Sawaya AC, Cunha IB, Carvalho PO, Eberlin MN. Phenolic antioxidants identified by ESI-MS from Yerba maté (Ilex paraguariensis) and green tea (Camelia sinensis) extracts. Molecules 2007; 12: 423-32.

[12] Schinella GR, Troiani G, Dávila V, de Buschiazzo PM, Tournier HA. Antioxidant effects of an aqueous extract of Ilex paraguariensis. Biochemical and Biophysical Research Communications 2000; 269: 357-60.

[13] Miranda DD, Arçari DP, Pedrazzoli J Jr, Carvalho Pde O, Cerutti SM, Bastos DH, Ribeiro ML. Protective effects of mate tea (Ilex paraguariensis) on $\mathrm{H} 2 \mathrm{O} 2$-induced DNA damage and DNA repair in mice. Mutagenesis 2008; 23: 261-5.

[14] Mosimann AL, Wilhelm-Filho D, da Silva EL. Aqueous extract of Ilex paraguariensis attenuates the progression of atherosclerosis in cholesterol-fed rabbits. BioFactors 2006; 26: 59-70.

[15] Martins F, Suzan AJ, Cerutti SM, Arçari DP, Ribeiro ML, Bastos $\mathrm{DH}$, Carvalho $\mathrm{P}$ de O. Consumption of mate tea (Ilex paraguariensis) decreases the oxidation of unsaturated fatty acids in mouse liver. British Journal of Nutrition 2009; 101: 527-32.

[16] Laranjinha J, Vieira O, Almeida L, Madeira V. Inhibition of metmyoglobin/H2O2-dependent low density lipoprotein lipid peroxidation by naturally occurring phenolic acids. Biochemical Pharmacology 1996; 51: 395-402.

[17] Gugliucci A, Bastos DH. Chlorogenic acid protects paraoxonase 1 activity in high density lipoprotein from inactivation caused by physiological concentrations of hypochlorite. Fitoterapia 2009; 80: $138-42$.

[18] Silva EL, Neiva TJC, Shirai M, Terao J, Abdalla DSP. Acute ingestion of yerba mate infusion (Ilex paraguariensis) inhibits plasma and lipoprotein oxidation. Food Research International 2008; 41: 973-9.

[19] Gugliucci A. Antioxidant effects of Ilex paraguariensis: induction of decreased oxidability of human LDL in vivo. Biochemical and Biophysical Research Communications 1996; 224: 338-44.

[20] Menini T, Heck C, Schulze J, de Mejia E, Gugliucci A. Protective action of Ilex paraguariensis extract against free radical inactivation of paraoxonase-1 in high-density lipoprotein. Planta Medica 2007; 73: 1141-7.

[21] Rizzo M, Kotur-Stevuljevic J, Berneis K, Spinas G, Rini GB, Jelic-Ivanovic Z Spasojevic-Kalimanovska V, Vekic J. Atherogenic dyslipidemia and oxidative stress: a new look. Translational Research 2009; 153: 217-23.

[22] Sitia S, Tomasoni L, Atzeni F et al. From endothelial dysfunction to atherosclerosis. Autoimmunity Reviews 2010; 9: 830-4.

[23] Muccillo Baisch AL, Johnston KB, Paganini Stein FL. Endothelium-dependent vasorelaxing activity of aqueous extracts 
of Ilex paraguariensis on mesenteric arterial bed of rats. Journal of Ethnopharmacology 1998; 60: 133-9.

[24] Schinella G, Fantinelli JC, Mosca SM. Cardioprotective effects of Ilex paraguariensis extract: evidence for a nitric oxide-dependent mechanism. Clinical Nutrition 2005; 24: 360-6.

[25] Paganini Stein FL, Schmidt B, Furlong EB, Souza-Soares LA, Soares MC, Vaz MR, Muccillo Baisch AL. Vascular responses to extractable fractions of Ilex paraguariensis in rats fed standard and high-cholesterol diets. Biological Research for Nursing 2005; 7: 146-56.

[26] Lanzetti M, Bezerra FS, Romana-Souza B, Brando-Lima AC, Koatz VL, Porto LC, Valenca SS. Mate tea reduced acute lung inflammation in mice exposed to cigarette smoke. Nutrition 2008; 24: 375-81.

[27] Puangpraphant S, de Mejia EG. Saponins in yerba mate tea (Ilex paraguariensis A. St.-Hil) and quercetin synergistically inhibi iNOS and COX-2 in lipopolysaccharide-induced macrophages through NFkappaB pathways. Journal of Agricultural and Food Chemistry. 2009; 57: 8873-83.

[28] Gao H, Liu Z, Qu X, Zhao Y. Effects of Yerba Mate tea (Ilex paraguariensis) on vascular endothelial function and liver lipoprotein receptor gene expression in hyperlipidemic rats. Fitoterapia 2013; 84: 264-72.

[29] Kádár A, Glasz T. Development of atherosclerosis and plaque biology. Cardiovascular Surgery 2001; 9: 109-21.

[30] Andrews TC, Ballantyne CM, Hsia JA, Kramer JH. Achieving and maintaining National Cholesterol Education Program low-density lipoprotein cholesterol goals with five statins. The American Journal of Medicine 2001; 111: 185-91.

[31] Sever PS, Dahlöf B, Poulter NR, Wedel H, Beevers G, Caulfield $\mathrm{M}$ et al. Prevention of coronary and stroke events with atorvastatin in hypertensive patients who have average or lower-than-average cholesterol concentrations, in the Anglo-Scandinavian Cardiac Outcomes Trial-Lipid Lowering Arm (ASCOT-LLA): a multicentre randomised controlled trial. Lancet 2003; 361: 114958.

[32] Bravo L, Mateos R, Sarriá B, Baeza G, Lecumberri E, Ramos S, Goya L. Hypocholesterolaemic and antioxidant effects of yerba mate (Ilex paraguariensis) in high-cholesterol fed rats. Fitoterapia 2014; 92: 219-29.

[33] Gao H, Long Y, Jiang X, Liu Z, Wang D, Zhao Y, Li D, Sun BL. Beneficial effects of Yerba Mate tea (Ilex paraguariensis) on hyperlipidemia in high-fat-fed hamsters. Experimental Gerontology 2013; 48: 572-8.

[34] Pang J, Choi Y, Park T. Ilex paraguariensis extract ameliorates obesity induced by high-fat diet: potential role of AMPK in the visceral adipose tissue. Archives of Biochemistry and Biophysics 2008; 476: 178-85

[35] Martins F, Noso TM, Porto VB, Curiel A, Gambero A, Bastos DH, Ribeiro ML, Carvalho Pde O. Maté tea inhibits in vitro pancreatic lipase activity and has hypolipidemic effect on high-fat dietinduced obese mice. Obesity 2010; 18: 42-7.

[36] Arçari DP, Bartchewsky W, dos Santos TW et al. Antiobesity effects of yerba maté extract (Ilex paraguariensis) in high-fat dietinduced obese mice. Obesity 2009; 17: 2127-33.

[37] Oliveira DM, Freitas HS, Souza MF, Arçari DP, Ribeiro ML, Carvalho PO, Bastos DH. Yerba Maté (Ilex paraguariensis) aqueous extract decreases intestinal SGLT1 gene expression but does not affect other biochemical parameters in alloxan-diabetic Wistar rats. Journal of Agricultural and Food Chemistry 2008; 56: 10527-32.
[38] de Morais EC, Stefanuto A, Klein GA, Boaventura BC, de Andrade F, Wazlawik E, Di Pietro PF, Maraschin M, da Silva EL. Consumption of yerba mate (Ilex paraguariensis) improves serum lipid parameters in healthy dyslipidemic subjects and provides an additional LDL-cholesterol reduction in individuals on statin therapy. Journal of Agricultural and Food Chemistry 2009; 57: 8316-24.

[39] Hosttetmann K, Marston A. Saponins. Cambridge University Press, New York, 1995.

[40] Ferreira F, Vázquez A, Güntner C, Moyna P. Inhibition of the Passive Diffusion of Cholic Acid by the Ilex paraguariensis St. Hil. Saponins. Phytotherapy Research 1997;11:79-81

[41] Han LK, Zheng YN, Xu BJ, Okuda H, Kimura Y. Saponins from platycodi radix ameliorate high fat diet-induced obesity in mice. Journal of Nutrition 2002; 132: 2241-45.

[42] Han LK, Zheng YN, Yoshikawa M, Okuda H, Kimura Y. Antiobesity effects of chikusetsusaponins isolated from Panax japonicus rhizomes. BMC Complementary and Alternative Medicine 2005; 5: 9 .

[43] Rodriguez de Sotillo DV, Hadley M. Chlorogenic acid modifies plasma and liver concentrations of: cholesterol, triacylglycerol, and minerals in $(\mathrm{fa} / \mathrm{fa})$ Zucker rats. The Journal of Nutritional Biochemistry 2002; 13: 717-26.

[44] Yeh YH, Lee YT, Hsieh HS, Hwang DF. Dietary caffeic acid, ferulic acid and coumaric acid supplements on cholestero metabolism and antioxidant activity in rats. Journal of Food and Drug Analysis 2009; 17: 123-32.

[45] Resende PE, Verza SG, Kaiser S, Gomes LF, Kucharski LC, Ortega GG. The activity of mate saponins (Ilex paraguariensis) in intra-abdominal and epididymal fat, and glucose oxidation in male Wistar rats. Journal of Ethnopharmacology 2012; 144: 735-40.

[46] Andersen T, Fogh J. Weight loss and delayed gastric emptying following a South American herbal preparation in overweight patients. Journal of Human Nutrition and Dietetics 2001; 14:24350.

[47] Ranilla LG1, Kwon YI, Apostolidis E, Shetty K. Phenolic compounds, antioxidant activity and in vitro inhibitory potential against key enzymes relevant for hyperglycemia and hypertension of commonly used medicinal plants, herbs and spices in Latin America. Bioresource Technology 2010; 101:4676-89.

[48] Kang YR, Lee HY, Kim JH et al. Anti-obesity and anti-diabetic effects of Yerba Mate (Ilex paraguariensis) in C57BL/6J mice fed a high-fat diet. Laboratory Animal Research. 2012; 28:23-9.

[49] Hussein GM1, Matsuda H, Nakamura S, Akiyama T, Tamura K, Yoshikawa M. Protective and ameliorative effects of maté (Ilex paraguariensis) on metabolic syndrome in TSOD mice. Phytomedicine 2011; 9:88-97.

[50] Silva RD1, Bueno AL, Gallon CW, Gomes LF, Kaiser S, Pavei C, Ortega GG, Kucharski LC, Jahn MP. The effect of aqueous extract of gross and commercial yerba mate (Ilex paraguariensis) on intra-abdominal and epididymal fat and glucose levels in male Wistar rats. Fitoterapia 2011; 82:818-26.

[51] Pereira DF, Kappel VD, Cazarolli LH, Boligon AA, Athayde ML, Guesser SM, Da Silva EL, Silva FR. Influence of the traditiona Brazilian drink Ilex paraguariensis tea on glucose homeostasis. Phytomedicine 2012; 19:868-77.

[52] Klein GA, Stefanuto A, Boaventura BC, de Morais EC, Cavalcante L da S, de Andrade F, Wazlawik E, Di Pietro PF, Maraschin M, da Silva EL. Mate tea (Ilex paraguariensis) improves glycemic and lipid profiles of type 2 diabetes and prediabetes individuals: a pilot study. Journal of the American College of Nutrition 2011; 30:320-32. 